\title{
Capital Structure Determinants: The Malaysian Manufacturing Industry's Evidence
}

\author{
M. Hafiz Ali, A.K.M. Nordin, M.K. Mat, Z. Zoolkefli, N. F. Z. Abidin
}

Universiti Teknologi MARA, Malaysia

Correspondence Author: M. Hafiz Ali, Universiti Teknologi MARA, Malaysia.

Received date: 22 December 2017, Accepted date: 22 January 2018, Online date: 5 February 2018

Copyright: (c) 2018 M. Hafiz Ali. This is an open-access article distributed under the terms of the Creative Commons Attribution License, which permits unrestricted use, distribution, and reproduction in any medium, provided the original author and source are credited.

\begin{abstract}
This study examined the relationship and impact of firms' factors in determining capital structure of Malaysian manufacturing firms. Malaysia's manufacturing production experienced a huge decline between the years 2008 to 2009 due to global financial crisis, with a production averaged only 5.20 percent from 1991 until 2016. Hence it is important to study the determinants of capital structure as it would help these firms to strategically balance between equity and debt as their source of capital for day-to-day operations and future growth. The developed model indicates that measures of firms' profitability, size, holding of tangible assets, volatility in earnings and liquidity are enough to determine 72 percent of firms capital structure. The result shows that larger firms would favour debt over equity, while firms with higher profit, asset's tangibility, earnings volatility and liquidity prefer equity as their source of capital. The findings agree with classical theories such as pecking order theory and trade-off theory.
\end{abstract}

Key words: Capital structure Determinants Manufacturing industry Malaysia

\section{INTRODUCTION}

The debate on capital structure determinants and firm value is no stranger to the world's corporate financial studies. Many theoretical and empirical researches have addressed these issues, but there has yet to be a unanimous accepted theory.

The first modern theory of capital structure developed by Modigliani and Miller [32] debates that the choice between debt and equity financing has no effect on the firm value. This debt irrelevance theorem which is based on restrictive assumptions, however do not hold in reality. Consequently, the choice of capital structure becomes an important matter in determining the value a firm. Furthermore, according to Myers [33] debt becomes the measurement for capital structure and conflict between debt holders and shareholders arises only in existance of default risk. If debt is default-free, debt holders have no interest in the income, value or risk of the firm. However, if possibility of default is significant, then shareholders can attain benefits at the expense of debt holders. Hence, the managers can bring into play numerous options while transferring value from debt holders to shareholders. Pecking order theory [13], predicts that firms prefer to use internal financing when available and will choose debt over equity when external financing is required.

Manufacturing industry is very important to the development of Malaysia. Manufacturing sector is one of the goods-producing industries supersector group. The manufacturing sector includes authorized engaged in the mechanical, physical or chemical transformation of materials, substances, or compnents into new products. Manufacturing industries are significant for an economy as they engage a large share of the workers force and make materials needed by sectors of strategic significance such as global infrastructure and defense.

From the Department of Statistics Malaysia, Malaysia's manufacturing production experienced a huge decline between the years 2008 to 2009 , due to the effect of the global financial crisis. Malaysia's manufacturing production averaged only 5.20 percent from 1991 until 2016.

Brownbill [8] states that a stunt in employment suggests that firms were more careful towards the outlook of the Malaysian economy. The report states that the decrease in demand encouraged firms to reduce inventories, which subsequently reduces firm's income and ability to pay debt. This shows worsening operating conditions in Malaysia's manufacturing sector.

Malaysia's target export is to achieve between 4 and 4.5 percent of growth in gross domestic product per year. However, with the slowing global demand and weakening Ringgit value the export advantages of Malaysia have been negated. Malaysia's trade balance fell to RM6.8 billion in the last quarter, down from RM11.4 billion in the final three months of 2015.

Hence, it is of the utmost importance to study the determinants of capital structure as it would help manufacturing firms in Malaysia to strategically balance between equity and debt as their source of capital for day-to-day operations and future growth.

Furthermore, capital structure is very important as it can affect the shareholder's return. Therefore, issues that are related to capital structure have to be figure out quickly because it is directly influence the firm's performance.

Literature Review:

The relationship between capital structure decisions and firm value has been extensively investigated in the past decades, in order to determine the optimal debt level. Past studies that delved in this matter have reached contrasting conclusions through a wide array of methodologies and approaches.

This may be due to the fact that theories concerning capital structure differ in their relative emphasis; where, the trade-off theory [31], emphasizes taxes, the pecking order theory [13], emphasizes differences in information, and the free cash flow theory [21] emphasizes agency costs. However, these theories do provide some help in understanding the financing behavior of firms as well as in identifying the potential factors that affect the capital structure.

Firms would prefer internally generated funds if it costs less than the investment outlays. Firms would reduce their cash balance or marketable securities portfolio and when external finance is required they would issue safe debt, followed by risky debt, hybrid securities and equity as the last resort. Moreover, the 
refinement work of Myers [33] led to the conclusion that company's stock price will fall following an extensive issuance of new stocks to finance new investments and this issue can be curbed if the new investment is financed with riskless debt.

The use of debt in the capital structure of a firm leads to agency costs. Therefore, agency costs stem as a result of the relationships between managers and shareholders, and those between debt holders and shareholders [22]. Kim and Sorensen [26] have extensively studied agency with findings that are consistent with previous studies. They find that high-growth firms have lower debt ratio, firms with higher insider ownership have greater debt ratios than firms with lower insider ownership, and debt is also positively correlated with operating risk, but is not correlated with firm size.

Conversely, in an agency model the principal suffers asymmetric information and pecking order theory states that inefficiencies in the firm's investment decisions caused by asymmetric information can be mitigated by the choice of a particular capital structure. Analysing a sample of Spanish firms, de Miguel and Pindado found that assets characteristics play an important role in the optimal debt-equity ratio. As investors perceive higher default probability and observe that the firm's assets are more specific, they require a higher lending rate and this higher risk premium discourages the use of debt.

Similar to pecking order theory, the market timing theory by Baker and Wurgler [2], does not predict the existence of an optimal capital structure, but is largely the cumulative outcome of past attempts to opportunistically time the equity market. According to this theory, firms with high-investment opportunities and high market to book values, tend to raise funds largely through new equity offerings and consequently end up with low-debt ratios.

Moreover, in a signalling model insiders are assumed to have private information rather than outsiders. Hence, firms' characteristics and opportunities send signal of firms' choice of capital structure. Ross [37] developed an incentive-signalling model in which managers are penalized if the firm goes bankrupt. Since, higher levels of debt mean higher bankruptcy probability and cost, low-quality firms will have lower debt ratios than high-quality firms.

Other signalling model developed by Poitevin [36] who considers a low-cost and high-quality entrant has an incentive to signal its true quality to the financial markets through its capital structure. In equilibrium, high-quality entrants issue debt and low-quality entrants and the incumbent issue only equity. This is inconsistent with the study of Ross [37].

Leland and Pyle's [27] claims that an entrepreneur's willingness to invest in a project serves as a signal of its true quality. Lenders will then translate this information into financial values. The firm or project value is directly correlated with the share of firm owned by the entrepreneur and firms with riskier returns are less levered.

Blazenko [5] demonstrated rational-expectations signalling by risk averse managers with private information, in which firms with better investment opportunities use debt financing. Furthermore, if debt is risky and value of collateral increases they will reduce debt financing. A bigger size of firms' fixed assets will lead to smaller equity under-pricing and reduce in debt financing.

John [23] summarized that capital structure choices are explained by theories based on input market considerations, industry specificities, equity ownership and the market for corporate control. Positive re-evaluation of a firm follows from an increasing change of risky debt in the capital structure, where issuance of bonds by growth firms are subjected to more restrictive covenants, compared to more established firms.

Titman [41] points out the agency relationship between a firm and individuals such as workers, suppliers and customers, where in the event liquidation firms can impose high costs on their principals and have lower debt to equity ratios.

Sarig [39] shows the higher the degree of leverage leads to higher bankruptcy probability if a production factor is highly specific to a firm. This brings empirical evidence on factors that affect debt to equity ratio of a firm, where shareholders' of highly levered firms have more bargaining power and consequently can negotiate better contract terms.

Bradley et al. [7] found that usage of debt in firms' capital structure depends on the specific industry the firms belong to. There are evidences of strong differences across industries, intra-industry dispersion is more limited and firms in more regulated industries have on average more debt in their capital structure. When financial distress costs are relevant, optimal firm leverage is inversely related to the volatility of earnings, R\&D and advertising expenditures and positively related to non-debt tax shields. Balakrishnan and Fox [3] also investigated leverage effects and industry characteristics, but no unanimous consensus has been reached.

Since equity carries voting rights and debt does not, capital structure has a direct impact on the probability of a firm being taken over. A firm that is a takeover target is more highly levered than a firm value. If managers own a large amount of the firm's equity, debt is expected to be largely used [19,26]. Agrawal and Nagarajan [1] show how in all-equity firms top managers have higher equity ownership than in levered firms. Managerial stockholdings are positively correlated with the family involvement in the operations and family involvement is greater in all-equity firms. Moreover, greater liquidity is available for all-equity firms than levered ones.

Manufacturing firm, especially when fully operational, are considered relatively low in volatility and easily managed. Opportunities for making major mistakes are thus limited and outside investors have stronger monitoring power thus reducing the potential agency problems between equity and debt holders. Geltner and Miller [17] state a larger amount of debt can be borrowed against the value of the underlying asset and therefore real estate investments should be characterized by higher debt to loan value compared to service corporations.

According to a study by Zeitun and Tian [46] on Jordanian firms, there is an important and negative impact between firm's capital structure and firm's performance either using accounting or market measurement. The study also claims that firm size is positively related to firm's performance because of large firms have low bankruptcy costs.

Since the value of the firm is directly related to its performance, economists study the relationship between leverage and firm performance in order to further prove Jensen's [21] theory. Empirical studies have not reached a unified agreement regarding the relationship between leverage and firm performance. Coricelli $e t$ al. [9] study on Central and Eastern European companies showed hump-shaped relationship between the level of debt and productivity growth. Moreover, classical studies of Harris and Raviv [18] and Titman and Wessel [42] also lead to different empirical results in basic facts of capital structure, which further cemented that the relationship between leverage and firm performance is still inconclusive.

\section{Methodology:}

Sample \& Data Collection:

The final sample for this study consists of 184 out of a total of 243 listed manufacturing companies in Bursa Malaysia. 59 companies were omitted due to insufficient data. A total of 1,840 data on firms financial positions are collected from Bursa Malaysia over the period of 10 years between the years 2006 until 2015.

\section{Model Development:}

The model develop in this study is grounded by three main theories; pecking order theory [13], agency theory [22] and trade-off theory [31]. Based on these theories debt ratio is selected as the dependent variable. Debt ratio $\left(D R_{i t}\right)$ is calculated by dividing firms' total debt with total asset.

Pecking order theory is based on two assumptions (1) the managers are better informed about their own firm's prospects than are outside investors and (2) managers act in the best interests of existing shareholders. Under these conditions, a firm will sometimes forgo positive net present value projects if accepting them forces the firm to issue undervalued equity to new investors. This in turn provides a rationale for firms to value financial slack, such as large cash and unused debt capacity. More specifically, pecking order theory predicts that firms prefer to use internal financing when available and choose debt over equity when external financing is required.

According to the agency theory, the use of debt in the capital structure of a firm can lead to agency cost; a type of internal cost because of core problems, such as conflicts of interest between shareholders and management.

While, trade-off theory states that conflict between debt holders and shareholders only arise when there is a risk of default. If debt is totally free of default risk, debt holders have no interest in the income, value or risk of the firm.

Furthermore, several supporting theories are used in determining the selection of independent variables. These variables are selected based on thorough literature review. Variables such as profitability, size, non-debt tax shields, tangibility, growth opportunities, earnings volatility and liquidity; are believed to be relevant determinants in explaining capital structure. 
Trade-off theory [31] is used in the selection of size $\left(S I Z E_{i t}\right)$, growth opportunities $\left(G R O W_{i t}\right)$, and liquidity $\left(L I Q_{i t}\right)$ as variables. According to Rajan and Zingales [38] large firms should borrow more as they have a lower probability towards default. This is consistent with the predictions of the trade-off theory which suggest that bigger firms should borrow more because these firms are more diversified, less risk towards bankruptcy and also lower bankruptcy cost. Furthermore, larger firms also have lower agency cost. Size $\left(S I Z E_{i t}\right)$ of firms is calculated by log of sales.

Since growth opportunities $\left(G R O W_{i t}\right)$ cannot be collateralized, firms tend to borrow less while holding more future growth opportunities, which are a form of intangible assets, suggesting a negative relationship between leverage and growth opportunities. It is measured by dividing firms' sales growth with total asset

Trade-off theory also suggests that companies with higher liquidity ratios $\left(L I Q_{i t}\right)$ should borrow more due to their ability to meet contractual obligations on time, indicating positive linkage between liquidity and leverage.

Pecking order theory is used for selection of profitability $\left(P R O F_{i t}\right)$ as proxy. The theory suggests firms prefer to use internally generated funds when available and choose debt over equity whenever external financing is needed, signifying a negative relationship between profit and debt. Profitability $\left(P R O F_{i t}\right)$ is calculated by dividing firms' earnings before interest and tax with total asset.

DeAngelo and Masulis [10] argue that tax deductions for depreciation and investment tax credits are substitutes for the tax benefits of debt financing. As a result, firms with large non-debt tax shields $\left(N D T S_{i t}\right)$ relative to their expected cash flow include less debt in their capital structures. Non-debt tax shields $\left(N D T S_{i t}\right)$ is calculated by dividing firms' depreciation expenses with total asset.

Myers and Majluf [35] argued that firms may find it advantageous to sell secured debt because there are some costs associated with issuing securities in which the firm's managers have better information about. Thus, issuing debt secured by the property with known values avoids these costs. This suggests a positive relationship between tangibility $\left(T A N G_{i t}\right.$ ) and leverage because firms holding assets can use these assets to lenders as collateral and issue more debt to take the advantage of this opportunity. Tangibility $\left(T A N G_{i t}\right)$ is calculated by dividing firms' fixed asset with total asset.

Several empirical studies have shown that a firm's optimal debt level is a decreasing function of the volatility of its earnings $\left(E V O L_{i t}\right)$. A higher volatility of earnings may indicate greater probability of a firm being unable to meet its contractual claims. Earnings volatility $\left(E V O L_{i t}\right)$ is measure by dividing standard deviation of firms' earnings before interest and tax with average total asset.

Based on these theories and empirical findings, the model is developed as follows:

$D R_{i t}=\beta_{0}+\beta_{1} P R O F_{i t}+\beta_{2} S I Z E_{i t}+\beta_{3} N D T S_{i t}+$

$\beta_{4} T A N G_{i t}+\beta_{5} G R O W_{i t}+\beta_{6} E V O L_{i t}+\beta_{7} L I Q_{i t}+\varepsilon_{i t}$

Results:

Descriptive Analysis:

Table 1: Summary of Descriptive Statistics

\begin{tabular}{|c|c|c|c|c|c|c|c|c|}
\hline & DR & PROF & SIZE & NDTS & GROW & TANG & EVOL & LIQ \\
\hline Mean & 0.3893 & 0.0310 & 8.2424 & 0.0338 & -0.0310 & 0.4977 & 0.0471 & 2.7275 \\
\hline Maximum & 1.7320 & \begin{tabular}{|l|}
0.8438 \\
\end{tabular} & 10.1786 & 0.4036 & 0.8438 & 1.3956 & 0.3739 & 44.5899 \\
\hline Minimum & 0.0176 & -0.9514 & 5.9421 & 0.0001 & -0.9514 & 0.0326 & 0.0000 & 0.0316 \\
\hline Std. Dev. & 0.2032 & 0.1017 & 0.6391 & 0.0221 & 0.1017 & 0.1737 & 0.0473 & 3.1518 \\
\hline Skewness & 0.7772 & -1.3611 & 0.1499 & 3.4477 & -1.3611 & 0.2133 & 2.1418 & 4.8286 \\
\hline Kurtosis & 2.0497 & 12.2804 & 0.2600 & 43.7556 & 12.2804 & 0.2067 & 6.3595 & 37.3610 \\
\hline
\end{tabular}

Table 1 provides summary of descriptive statistic of the study's collected sample. The sample consists of 184 listed manufacturing companies in Bursa Malaysia, with a total of 1,840 data on firms' financial positions.

The firms have a range in debt ratio $(D R)$ of 1.7144 and profit (PROF) of 1.7952. The firms have an average size (SIZE) of 8.2424 based on sales. Firms' non-debt tax shield (NDTS), growth opportunities $($ GROW) show relatively low average of 0.0338 and -0.0310 . The holding of tangible asset by firms recorded a mean 0.0326 of and a maximum of 1.3956 . Moreover, the sample shows that the firms' have low earnings volatility $(E V O L)$ with an average of 0.0471 . However, the firms have a rather large variation in range of liquidity $(L I Q)$ of 44.5583 .

\section{Correlation Analysis:}

452 outliers are found and removed, which result a total of 1,388 observations as the study's final sample. Outliers are removed according to the method as described by Hoaglin and Iglewicz [20]. The data is further transformed to normality.

Table 2 shows that five out of seven independent variables correlates signifcantly with debt ratio at $1 \%(p \leq 0.01)$. The variables are $P R O F$, SIZE, TANG, GROW and $L I Q$. All variables agreed to their predicted sign except for GROW and $L I Q$.

Moreover, the matrix indicates that the independent variables do correlates significantly with one another. PROF correlates significantly with all of the other independent variables at $1 \%(p \leq 0.01)$. Hovewer, they are not strongly correlated as the $r$-value is less than 0.5 . All the other independent variables that correlate with one another have weak correlations $(r<0.5)$.

Pearson correlation matrices present possibility of multicollinearity, which will be a problem in examining multivariate regressions. Malhotra [28] confirms that multicollinearity is not a serious problem when the correlation coefficients are below 0.75 . As observed from the correlation matrix, it is found that most of the independent variables had low correlation with the one another. Hence, this indicates that muticollinearity is not a problem in this study.

Multiple Regression Analysis:

In examining the determinants of capital structure, multiple regression analysis is used to further investigate the simultaneous effect of all the variables. This study (1) examines the relationship of the firms' factors in determining capital structure and (2) examines whether the selected firms' factors have have a significant impact in determining capital structure.

Table 3 presents the results of the multiple regression. The developed model has a $p$-value of zero to four decimal places, with F-test value of 510.722 signifying that the model is statistically significant. In addition, the model has an adjusted $R^{2}$ of 0.72 which indicates that about $72 \%$ of debt ratio's variability is explained by the variables included in the model.

Table 2: Pearson Correlation Coefficients

\begin{tabular}{|c|c|c|c|c|c|c|c|c|}
\hline $\mathrm{t}-$ Statistic & DR & PROF & SIZE & NDTS & TANG & GROW & EVOL & LIQ \\
\hline DR & 1.000 & & & & & & & \\
\hline PROF & $-0.335^{* *}$ & 1.000 & & & & & & \\
\hline SIZE & $0.270 * *$ & $0.202 * *$ & 1.000 & & & & & \\
\hline NDTS & -0.019 & $-0.189 * *$ & $-0.240 * *$ & 1.000 & & & & \\
\hline TANG & $0.075^{* *}$ & $-0.263 * *$ & -0.050 & $0.324 * *$ & 1.000 & & & \\
\hline GROW & $0.117 * *$ & $0.243^{* *}$ & $0.285^{*} *$ & $0.112 * *$ & $-0.398 * *$ & 1.000 & & \\
\hline EVOL & -0.047 & $-0.122 * *$ & 0.011 & 0.013 & 0.018 & -0.035 & 1.000 & \\
\hline LIQ & $-0.781^{* *}$ & $0.374 * *$ & $-0.221 * *$ & $-0.089 * *$ & $-0.450 * *$ & 0.009 & -0.001 & 1.000 \\
\hline
\end{tabular}

** Indicates significance at the 0.01 level. 
The result indicates that five out of seven variables are statistically significant at 0.01 level (PROF, SIZE, TANG, EVOL, and LIQ). Three out of five of the significant variables agreed to their predicted signs $(P R O F, S I Z E$ and $E V O L)$. Furthermore, the results present that with every one unit increase in firms' SIZE, it would yield a 0.03 unit increase in firms' $D R$. With every one unit increase in firms' $P R O F$ and firms' EVOL, they would yield a 0.351 and 0.121 decrease in firms' $D R$ respectively.

Two of the significant variable did not agree to their predicted sign (TANG and $L I Q)$. The result shows with every one unit increase in firms' TANG and firms' $L I Q$, they would yield a 0.406 and 1.136 decrease in firms' $D R$ respectively. The other two included variables (NDTS and GROW) are not a significant predictor of firms' $D R$.

Discussion:

The result of firms' profitability $(P R O F)$ as a negatively significant predictor of firm's debt $(D R)$ can be explained by pecking order theory. Firms' with large profit are often implied as financially stable and would prefer equity over debt as their financing choice. Other empirical findings that have similar results are Toy et al. [43], Titman and Wessels [42], Rajan and Zingales [38], Wald [45], Viviani [44] and Jong et al. [24].

Size of firms $(S I Z E)$ is proven to be a positively significant predictor of firm's debt ratio $(D R)$ which is consistent with trade-off theory. Large firms are more diversified and have lesser probability of default hence they should borrow more $[29,38,45,4,12,47,14,24,40]$.

Firms' volatility in earnings (EVOL) is also proven to be a positively significant predictor of firm's debt ratio $(D R)$. This result is agrees with pecking order theory, where firms with high volatility in earnings may indicate a greater default probability and firms' debt $[6,15,24]$.

Table 3: Relationship between Firms' Factors and Debt Ratio

\begin{tabular}{|l|l|l|}
\hline Variable & Predicted Sign & Coefficient \\
\hline & & 0.519 \\
\hline PROF & - & $(11.303)$ \\
\hline SIZE & + & $-0.351^{* *}$ \\
\hline & & $(-7.151)$ \\
\hline NDTS & - & $0.030^{* *}$ \\
\hline & - & $(5.797)$ \\
\hline GROW & & 0.222 \\
\hline & + & $(1.425)$ \\
\hline TANG & & -0.039 \\
\hline & - & $(-1.160)$ \\
\hline EVOL & & $-0.406^{* *}$ \\
\hline & + & $(-18.339)$ \\
\hline LIQ & & $-0.121^{* *}$ \\
\hline & 1388 & $(-4.030)$ \\
\hline No. of obeservations & $-1.136^{* *}$ \\
\hline R-squared & 0.721 & $(-47.784)$ \\
\hline Adjusted R-squared & 0.72 & \\
\hline Prob(F-statistic) & $510.722^{* *}$ & \\
\hline
\end{tabular}

** Indicates significance at the 0.01 level.

There are two significant independent variables that do not agree to their predicted signs (TANG and LIQ). According to agency theory firms' hold of tangible asset with known value should have a positive relationship with the firms' debt as it can be used as collateral to lenders, hence being the reason for firms to issue more debt $[22,34,35]$. However, Titman and Wessel [42] argued that if tangible asset cannot be collateralized, creditors may require a more favourable option such equity financing, resulting a negative relationship between tangible asset $(T A N G)$ and firms' debt $(D R)$. This argument is then supported with numbers of other empirical evidence $[16,6,4,30,25]$

As for firms' liquidity $(L I Q)$, trade-off theory suggests that firms with higher liquidity ratios should borrow more due to their ability to meet contractual obligations, predicting a positive relationship against firms' debt. In contrary, pecking order theory predicts a negative relationship due to the fact that firms with greater liquidity are financially sound to generate funds internally. Deesomsak et al. [12], Mazur [30] and Viviani [44] empirically support this claim.

\section{Limitations Of The Study:}

Findings of the study are limited to only manufacturing industry of Malaysia. Furthermore, eventhough the model fit of this study are significantly high with an adjusted adjusted $R^{2}$ of 0.72 , two of the variables selected failed to appear as a significant predictor of firms' capital structure (NDTS and GROW). Future studies on other factors that might have an influence on firms' capital structure are warranted.

\section{Conclusion:}

To conclude, this study indicates there is a significant relationship and impact between the firms' factors in determining capital structure. The multiple regression model uses firms' debt ratio as the measurement of capital structure.

It is noted that firms' factors are significant enough to explain firms' debt ratio. The model indicates that measures of firms' profitability, size, holding of tangible assets, volatility in earnings and liquidity are enough to determine 72 percent of firms' capital structure. The result shows that larger manufacturing firms in Malaysia would opt for debt over equity in their capital structure. Moreover, firms with higher profit, asset's tangibility, earnings volatility and liquidity prefer equity as their source of capital. These findings are hoped to help Malaysia's manufacturing firms in their strategy to achieve an optimum balance between equity and debt in their capital structure, as it agree with classical theories such as pecking order theory and trade-off theory. In addition, these findings are also inline numerous empirical studies $[42,38,30,24,44]$.

\section{REFERENCES}

[1] Agrawal, A. and N.J. Nagarajan, 1990. Corporate Capital Structure, Agency Costs, and Ownership Control: The Case of All-Equity Firms. The Journal of Finance, 45(4): 1325-1331.

[2] Baker, M. and J. Wurgler, 2002. Market Timing and Capital Structure. The Journal of Finance, 57: 1-32.

[3] Balakrishnan, S. and I. Fox, 1993. Asset Specificity, Firm Heterogeneity and Capital Structure. Strategic Management Journal, 14(1): 3-16.

[4] Bauer, P., 2004. Determinants of Capital Structure: Empirical Evidence from the Czech Republic. Czech Journal of Economics and Finance, 54(1-2): 2-21.

[5] Blazenko, G.W., 1987. Managerial Preference, Asymmetric Information, and Financial Structure. The Journal of Finance, 42: 839-862.

[6] Booth, L., V. Aivazian, A. Demirguc-Kunt and V. Maksimovic, 2001. Capital Structures in Developing Countries. The Journal of Finance, 56(1): 87-130.

[7] Bradley, M., G.A. Jarrell, E.H. Kim, 1984. On the Existence of an Optimal Capital Structure: Theory and Evidence. The Journal of Finance, 39(3): 857-878.

[8] Brownbill, A., 2016. Increased Employment in Malaysia's Manufacturing Sector. Retrieved from https://www.theiskandarian.com/web/tag/amy-brownbill/

[9] Coricelli, F., N. Driffield, S. Pal and I. Roland, 2011. Optimal leverage and firm performance: An endogenous threshold analysis. 
[10] DeAngelo, H. and R.W. Masulis, 1980. Optimal Capital Structure Under Corporate and Personal Taxation. Journal of Financial Economics, 8(1): 3-27.

[11] de Miguel, A. and J. Pindado, 2001. Determinants of Capital Structure: New Evidence from Spanish Panel Data. Journal of Corporate Finance, 79(1): 77-99.

[12] Deesonsak, R., K. Paudyal and G. Pescetto, 2004. The Determinants of Capital Structure: Evidence from the Asia Pacific Region. 14(4-5): 387-405.

[13] Donaldson, G., 1961. Corporate Debt Capacity: A Study of Corporate Debt Policy and The Determination of Corporate Debt Capacity, Boston, Division of Research, Harvard Graduate School Of Business Administration.

[14] Eriotis, N., D. Vasiliou and Z. Ventoura-Neokosmidi, 2007. How Firm Characteristics Affect Capital Structure: An Empirical Study. Managerial Finance, 33(5): 321-331

[15] Fama, E.F. and K.R. French, 2002. Testing Trade-off and Pecking Order Predictions about Dividends and Debt. The Review of Financial Studies, 15(1): 133.

[16] Ferri, M.G. and W.H. Jones, 1979. Determinants of Financial Structure: A New Methodological Approach. The Journal of Finance, 34(3): 631-644.

[17] Geltner, D., N.G. Miller, J. Clayton and P. Eichholtz, 2001. Commercial Real Estate Analysis and Investments, 1: 642.

[18] Harris, M. and A. Raviv, 1991. The theory of Capital Structure. The Journal of Finance, 46(1): 297-355.

[19] Harris, M. and A. Raviv, 1988. Corporate control contests and capital structure. Journal of financial Economics, 20: 55-86.

[20] Hoaglin, D.C. and B. Iglewicz, 1987. Fine-Tuning Some Resistant Rules for Outlier Labeling. Journal of the American Statistical Association, 82(400): 1147-1149.

[21] Jensen, M.C., 1986. Agency Costs of Free Cash Flow, Corporate Finance, and Takeovers. The American economic review, 76(2): 323-329.

[22] Jensen, M.C. and W.H. Meckling, 1976. Theory of the Firm: Managerial Behavior, Agency Costs and Ownership Structure, Journal of Financial Economics, 3(4): 305-360

[23] John, K., 1987. Risk-Shifting Incentives and Signalling Through Corporate Capital Structure. The Journal of Finance, 42: 623-641.

[24] Jong, A., R. Kabir and T. ThuNguyen, 2008. Capital Structure around the World: The Roles of Firm- and Country-Specific Determinants, Journal of Banking \& Finance, 32(9): 1954-1969.

[25] Karadeniz, E., S. Yilmaz Kandir, M. Balcilar and Y. Beyazit Onal, 2009. Determinants of Capital Structure: Evidence from Turkish Lodging Companies. International Journal of Contemporary Hospitality Management, 21(5): 594-609.

[26] Kim, W.S. and E.H. Sorensen, 1986. Evidence on the Impact of the Agency Costs of Debt on Corporate Debt Policy, The Journal of Financial and Quantitative Analysis, 21(2): 131-144.

[27] Leland, H.E. and D.H. Pyle, 1977. Informational Asymmetries, Financial Structure, and Financial Intermediation, The Journal of Finance, 32 (2): 371-387.

[28] Malhotra, N.K., 2004. Marketing Research: An Applied Orientation (4th edn) Pearson Education, Inc: New Jersey

[29] Marsh, P., 1982. The Choice Between Equity and Debt: An Empirical Study. The Journal of Finance, 37: 121-144.

[30] Mazur, K., 2007. The Determinants of Capital Structure Choice: Evidence from Polish Companies. International Advances in Economic Research, 13(4): 495-514.

[31] Miller, M.H., 1977. "Debt and Taxes". Journal of Finance, 32(2): 261-275.

[32] Modigliani, F. and M.H. Miller, 1958. The Cost of Capital, Corporation Finance and the Theory of Investment. The American Economic Review, 48(3): 261297.

[33] Myers, S.C., 2001. Capital Structure, The Journal of Economic Perspectives, 15(2): 81-102.

[34] Myers, S.C., 1977. Determinants of Corporate Borrowing. Journal of financial economics, 5(2): 147-175.

[35] Myers, S.C. and N.S. Majluf, 1984. Corporate Financing and Investment Decisions When Firms have Information that Investors do not have. Journal of Financial Economics., 13(2): 187-221.

[36] Poitevin, M., 1989. Financial Signalling and the "Deep-Pocket" Argument, The RAND Journal of Economics, 20(1): 26-40.

[37] Ross, S.A., 1977. The Determination of Financial Structure: The Incentive-Signalling Approach, The Bell Journal of Economics, 8(1): 23-40.

[38] Rajan, R.G. and L. Zingales, 1995. What Do We Know about Capital Structure? Some Evidence from International Data. The Journal of Finance, 50: 14211460.

[39] Sarig, O.H., 1998. The Effect of Leverage on Bargaining with a Corporation. Financial Review, 33: 1-16.

[40] Silva Serrasqueiro, Z.M. and M.C. Rêgo Rogão, 2009. Capital Structure of Listed Portuguese Companies: Determinants of debt Adjustment. Review of Accounting and Finance, 8(1): 54-75.

[41] Titman, S., 1984. The Effect of Capital Structure on a Firm's Liquidation Decision, Journal of Financial Economics, 13(1): 137-151.

[42] Titman, S. and R. Wessel, 1988. The Determinants of Capital Structure Choice. The Journal of Finance, 43: 1-19.

[43] Toy, N., A. Stonehill, L. Remmers, R. Wright and T. Beekhuisen, 1974. A Comparative International Study of Growth, Profitability, and Risk as Determinants of Corporate Debt Ratios in the Manufacturing Sector. Journal of Financial and Quantitative Analysis, 9(5): 875-886.

[44] Viviani, J.L., 2008. Capital Structure Determinants: An Empirical Study of French Companies in the Wine Industry, International Journal of Wine Business Research, 20(2): 171-194.

[45] Wald, J.K., 1999. How Firm Characteristics Affect Capital Structure: An International Comparison, Journal of Financial Research, 22: 161-187.

[46] Zeitun, R. and G.G. Tian, 2007. Capital Structure and Firm Performance: Evidence from Jordan. Australia Accounting Business and Finance Journal, 1(4): $148-168$.

[47] Zou, H. and J.Z. Xiao, 2006. The Financing Behaviour of Listed Chinese Firms. The British Accounting Review, 38(3): 239-258. 